Politica, Vol. 7, No. 1, Januari-Juni 2020

\title{
TURKISH STATE FAMILY LAW: HISTORY REFORM, LEGISLATION, AND LEGAL MATERIALS
}

\author{
Ali Hamzah \\ Institut Agama Islam Negeri (IAIN) Kerinci \\ alihamzah311268@gmail.com \\ Doli Witro \\ Institut Agama Islam Negeri (IAIN) Kerinci \\ doliwitro01@gmail.com \\ Ike Yulisa \\ Universitas Islam Negeri (UIN)ImanBonjol \\ ikeyulisa5@gmail.com \\ Mhd. Rasidin \\ Institut Agama Islam Negeri (IAIN) Kerinci \\ mhd_rasidin@yahoo.co.id \\ Syamsarina \\ Institut Agama Islam Negeri (IAIN) Kerinci \\ Syamsarina@gmail.com \\ Hainadri \\ Institut Agama Islam Negeri (IAIN) Kerinci \\ hainadri.1981@gmail.com
}

\begin{abstract}
:
Historically, efforts to reform Family Law in parts of the Islamic world began to be realized in the late 19 th century $\mathrm{AD}$. The reality of Islamic legal reforms carried out in Islamic countries in North Africa, the Middle East, Central Asia, and Southeast Asia gave rise to unprecedented changes in the last century. These changes occur both in the justice system and in the system applied. Changes to family law were first carried out by Turkey, then followed by Lebanon in 1919, Jordan in 1951, and Syria in 1953. Muslim countries in the world, in their context with the renewal of family law, are divided into three categories. First, an Islamic state that does not carry out any renewal and still enforces family law as stipulated in the books of fiqh. Secondly, an Islamic state that has completely abandoned Islamic family law and adopted European civil law. Third, countries that are trying to enforce Islamic family law but after making reforms here and there. This paper tries to discuss one of the reforms carried out by one Muslim country, namely Turkey, which is related to the reformation (reform) of family law that starts from the history of reform, legislation,
\end{abstract}


Politica, Vol. 7, No. 1, Januari-Juni 2020

renewal, and legal material. The author chose Turkey because it is the first Muslim country to make changes to family law.

Keywords: Family Law, Reform Law, Turkish Country

\begin{abstract}
Abstrak
Secara historis, upaya pembaharuan Hukum Keluarga di belahan dunia Islam mulai terealisasi pada penghujung abad 19 Masehi. Realitas reformasi hukum Islam yang dilakukan di negara-negara Islam di Afrika Utara, Timur Tengah, Asia Tengah dan Asia Tenggara melahirkan perubahan besar yang belum pernah terjadi sebelumnyapada satu abad terakhir. Perubahan tersebut terjadi baik dalam sistemperadilanmaupun dalam sistem yang diterapkan. Perubahan hukum keluarga pertama kali dilakukan oleh Turki, kemudian disusul oleh Lebanon pada tahun 1919, Yordania tahun 1951 dan Syiria pada tahun 1953.Negara-negara muslim di dunia ini dalam konteksinya dengan pembaharuan hukum keluarga pada dasarnya terbagi atas 3 kategori. Pertama, negara Islam yang sama sekali tidak melakukan pembaharuan dan masih tetap memberlakukan hukum keluarga sebagaimana yang tertuang dalam kitab-kitab fiqh. Kedua, negara Islam yang sama sekali meninggalkan hukum keluarga Islam dan mengambil hukum sipil Eropa. Ketiga, negara-negara yang berusaha memberlakukan hukum keluarga Islam tapi setelah mengadakan pembaharuan di sana-sini. Tulisan ini mencoba membahas salah satu pembaharuan yang dilakukan oleh salah satu negara muslim, yaitu Turki, yang berkaitan dengan pembaharuan (reformasi) hukum keluarga yangdimulai dari sejarah reformasi, legilasi, pembaharuan, dan Materi Hukum. Penulis memilih negara Turki karena merupakan negara muslim yang pertama melakukan perubahan terhadap hukum keluarga.
\end{abstract}

Kata Kunci: Hukum Keluarga, Pembaharuan (Reformasi) Hukum, Negara Turki

\title{
Introduction
}

Islam is a perfect religion. One of its perfection is seen from the rule of law that must be enforced by Muslims (people who convert to Islam) wherever he is because Islamic law applies by itself and is binding on those who have stated that he converted to Islam, even though he is in the non-Muslim territory. ${ }^{1}$ Historically, efforts to reform Family Law in parts of the Islamic world began to be realized in the late 19 th century $\mathrm{AD} .{ }^{2}$ Public awareness fosters the spirit of renewal from the

${ }^{1}$ Encep Abdul Rojak, "Hukum keluarga di Dunia Islam (Perbandingan Kitab Majallatul Ahkam di Turki dan Kompilasi Hukum Islam di Indonesia)", Tahkim: JurnalPeradabandanHukum Islam, Vol. 2, No. 1, 2019, p. 15-16.

${ }^{2}$ Vita Fitria, "Hukum Keluarga di Turki Sebagai Upaya Perdana Pembaharuan Hukum Islam”, Humanika, Vol. 12, No. 1, 2012, p. 1. 
formulation of the old Law, which has been formatted towards a Law that is better able to accommodate the demands of the times and the progress of Islam itself.

The reality of Islamic legal reforms carried out in Islamic countries in North Africa, the Middle East, Central Asia, and Southeast Asia gave rise to unprecedented changes in the last century. These changes occur both in the justice system and in the system applied. Changes to family law were first made by Turkey when publishing“'Ottoman Law of Family Rights" (Qanun Qarar al-Huquq al-'AilahalUthmaniyyah) in 1917, then followed by Lebanon in 1919, Jordan in 1951 and Syria in $1953 .^{3}$

In the nation and state of Turkey, the motto is Yurta Sulh, Cihandra Sulh (Peace at home, Peace in the world). Turkey is not a religious country, although its population is $98 \%$ diverse in Islam, and $2 \%$ are Jewish, Roman Catholic, and followers of several eastern Orthodox groups. However, the state guarantees religious freedom for its inhabitants. ${ }^{4}$

There are many differences in implementing Islamic law in the context of family law invitations among modern Muslim countries, some even in contradiction. Tunisia and Turkey, for example, have practiced Islamic law with the utmost liberality, this cannot be separated from the historical context of the history of the two countries in applying the law in the life of the nation's people. In contrast to the two countries above, Saudi Arabia, the United Arab Emirates, Bahrain, still use the application of Islamic law as in their fiction books. In the two currents, many countries emerged that tried to apply the law in their respective countries by trying to bridge between the urgent basic needs and the wealth that was still functioning, and many modern Muslim nation-states shared this in general. Not to mention that Iran which has a mazhab Syi'ah its characteristics in the application of family law. ${ }^{5}$

Muslim countries in the world, in its context with the renewal of family law, are divided into three categories: First, an Islamic state that does not carry out any renewal and still enforces family law as stipulated in the books of fiqh. An example of this category is Saudi Arabia; Secondly, an Islamic state that has completely abandoned Islamic family law and adopted European civil law. For example, Turkey;

3 Suchamdi, "Heterogeneous Perundang-UndanganHukumPerkawinan Negara-Negara Muslim Modern”, Kodifikasia: JurnalPenelitian Islam, Vol. 7, No. 1, 2013, p. 24.

${ }^{4}$ FitriyaniZein, "Kekerasan Dalam Perkawinan dan Nusyuz dalam Hukum Keluarga di Turki, Malaysia, Sudan, Yordan, dan Indonesia”, Salam: Jurnal Sosial dan Budaya Syar'I, Vol. 4, No. 1, 2017, p. 123.

5 Miftahul Huda, "Ragam Bangunan Perundang-Undangan Hukum Keluarga di NegeraNegara Muslim Modern (KajianTipologis)”, Al-Manahij: JurnalKajianHukum Islam, Vol. 11, No. 1, 2017 , p. 50. 
and Third, countries that are trying to enforce Islamic family law but after making reforms here and there. For example, Egypt, Pakistan, Tunisia, and Indonesia are countries in this category. ${ }^{6}$

This paper tries to discuss one of the reforms carried out by one Muslim country, namely Turkey, which is related to the reform of family law that starts from the history of reform, legislation, renewal, and legal material. The author chose Turkey because it was the first country to make changes to family law, as explained above.

\section{History of Family Law Reform in Turkey}

The intersection of Islam with Turkey through a long history, starting from the first century of Hijri until the Turkish tribes became adherents and defenders of Islam. When the Ottoman empire was still in power, the empire imposed a judicial and legal system that was combined with the sharia especially the jurisprudence of the mazhabHanafiwhere the court was directed to implement the decisions of various cases, and this system was supported by religious institutions independent of the Sultan's authority. At the top of its bureaucracy, this institution was led by a mufti (syaikh al-Islam). Mufti is chosen and can be dismissed at any time by a Sultan. The Sultan must not arbitrarily impose sharia law without legitimacy in the form of a fatwa from the mufti.On the other hand, the mufti has the authority to elect judges (qadi) who regulate the application of sharia throughout the kingdom. However, at the time of the fall of Ottoman rule, all of these religious institutions were no longer enforced. For systematization and codification of the legal system, in 1839, the Decree of the Imperium HattiSyarif was issued as a foundation for the current legislative regime. ${ }^{7}$

Furthermore, in anticipation of the rise of trade, in 1850-1858 AD, was issued a trade and criminal law which part of the formula was taken from the mazhabHanafi of law and some others from French law. Codification was carried out in conjunction with a wave of legal modernization and westernization, such as the establishment of Majallat al-Ahkam al-'Adliyah was the first civil law adopted in the Islamic world. In this last law, all of its legal material had not yet been reformed and had not been enacted until the 20th century. The political revolution which had devastated the Ottoman empire and deposed the Khalifah'soffice contributed to the change of the

\footnotetext{
${ }^{6}$ MahsunFuad, "DinamikaSekularisasi dan Pembaharuan Hukum Waris Islam di Turki", AlMabsut, Vol. 13, No.2, 2019, p. 12.

7 M. Atho' Muzdhar, Hukum Keluarga di Dunia Islam Modern, (Jakarta: Ciputat Press, 2003), p. 37-38.
} 
Civil Law of 1876 and the law the new family was established in 1915 and 1917, and the inheritance law in the mazhabHanafi of law had not yet been codified by the new Civil Law which was carried out in $1926 .{ }^{8}$

One of the monumental legacies of Turkish legal reform is the codification of the law of al-Majallat al-Ahkam al-Adliyahor al-Majallah in 1870, this became the Civil Code (Civil Code) throughout the Ottoman Empire and is considered the first Civil Code in the world Islam. The majority of al-Majallah's material legal resources are taken from the view of the mazhabHanafi of thought. In Turkey,al-Majallah was replaced with the Swiss Civil Code in 1926 as one of the effects of the secularisation carried out by the current Turkish government under the leadership of Mustofa Kemal Attaturk. ${ }^{9}$ The secularization of religion during the Kemalist period (1923-1950) gave birth to a Turkish generation that was far from its religion. Turkish written in Latin has become the national language of Turkey. While the use of Western laws is also adapted to varying degrees of difficulty in various levels of society. Turkey was born from the ruins of the Ottoman Empire after World War I, located in Asia Minor (Anatolia), founded by Mustofa Kemal Attaturk. Turkey became the first secular country in the Islamic world. ${ }^{10}$ Apart from that, although the role of al-Majallah in Turkey ended in 1926, al-Majallah persisted long enough in other regions that were once the Ottoman Empire so that new legal reforms such as Lebanon (1932), Syria (1949) and Iraq (1953). Even though legal reform has taken place, the material in alMajallah Turkey remains an important source of legal material in the new law. ${ }^{11}$

\section{Family Law Legislation 1915-1917}

In 1915, the kingdom issued a decree reforming matrimonial law (related to marriage) in the mazhabHanafi of thought, which was locally related to women's rights to divorce. In this decree, the principle of takhayyur (eclectic) is used by taking sources from the Hanbali and mazhabHanafis. In the decree stated that women are allowed to seek divorce on the basis of being abandoned by her husband or because of her illness. Two years later, the empire passed a Law on Matrimonial Law entitled QanuniQararHuquq al-'ilah al-Utsmania (Ottoman law governing family rights) in 1917 and this law only lasted for about two years. ${ }^{12}$

\footnotetext{
${ }^{8}$ M. Atho’ Muzdhar, HukumKeluarga di Dunia Islam Modern..., p. 37-38.

9 Ahmad Bunyan Wahid, "ReformasiHukumKeluarga di Dunia Muslim, Jurnal Wacana Hukum Islam dan Kemanusiaan, Vol. 14, No. 1, 2014,p. 3.

${ }^{10}$ Ahmad Zayyadi, "ReformasiHukum di TurkidanMesir (TinjauanHistoris-Sosiologis)", AlMazahib, Vol. 2, No. 1, 2014, p. 150.

${ }^{11}$ Ahmad Bunyan Wahid, "ReformasiHukumKeluarga di Dunia Muslim...,p.4.

${ }^{12}$ M. Atho’ Muzdhar, Hukum Keluarga di Dunia Islam Modern..., p. 39.
} 
Politica, Vol. 7, No. 1, Januari-Juni 2020

After the Laussane Peace Conference in 1923, the Turkish government formed a legal commission to prepare a new civil law. The commission tried to put the law on family rights in 1917 Majallat al-Ahkamal-Ardliyyah in 1876 and traditional unwritten law into a whole new law. However, the result of sharp differences of opinion among modernists and traditionalists resulted in chaotic and dissolved legal committees. ${ }^{13}$

\section{Civil Law 1926}

In 1923, after the Lausanne peace conference, a law reform commission was formed to draft a comprehensive draft civil law and personal status based on Islamic legal sources. However, the committee failed because of differences of opinion, which were motivated by differences in the vision and mission of the commission members. Another reason is that the time coincided with the destruction of the Islamic Khalifah and the declaration of Turkey as a Republic. Under Mustofa Kemal Attaturk's rule, the codification effort was resumed. The result was that in 1924 a new national constitution was adopted by adopting a civil law system. ${ }^{14}$

The adoption was carried out due to internal differences in religious jurists who failed to pursue laws based on sharia. Even so, adoption was only carried out on issues that were appropriate to the situation and condition of Turkey. For example, the Civil Law and Criminal Law issued in 1926, which were adopted from the Italian criminal law of 1889 and the Swiss Civil Law of 1920. Thus the new Turkish Civil Law did not fully adopt the Swiss Law Civil, but only a few parts. This confirms the statement that there are inherent potential and possibility that Islamic law has been taken into consideration before enacting a new law. The Turkish Civil Law of 1926 contains marriages, divorces, family relations, and inheritance, in addition to contracts and bonds. To adapt the Law to the Turkish Islamic tradition, amendments were made to the Civil Law of 1926 up to six times from 1933 AD-1965 AD ${ }^{15}$

\section{Reasons for the occurrence of Family Law Reform in Turkey}

The renewal of Islamic law in Muslim countries, especially after the conflict between Islam and the west, during colonialism. So, this post-colonialism renewal also took place in several newly independent Muslim countries. When Muslims come into contact with a more advanced West, they come to think, why do Muslims

${ }^{13}$ Suardi Abbas, "Keberanjakan dari Konsep Konvensiona lkedalam Perundang-undangan Hukum Keluarga Islam”, Asas, Vol. 8, No. 2, 2016, p. 34.

${ }^{14}$ Tahir Mahmood, Family Law Reform in The Muslim World, (Bombay: Tripathi, 1972), p. 264-265

${ }^{15}$ M. Atho' Muzdhar, Hukum Keluarga di Dunia Islam Modern..., p.40-41. 
experience a setback, and the West becomes more advanced? Responses and responses of Muslims towards the west -related to the progress of the West and the decline of Muslims- differ. First, some reject the west, so that their renewal is the purification of Islam. According to them, Muslimsretreat because it has left pure Islamic teachings. So to get progress, Muslims must return to the teachings of pure Islam. On the other hand, some see the West more advanced, then immediately adopt the Western system and abandon the Islamic system -especially the Khilafah- for example, Turkey, immediately dissolve the Caliphate and change the Ottoman Turkey into the Secular Turkish Republic, and adopt the Western criminal and civil law system. Besides these two groups, there are groups who want to adopt the good side that comes from the West, and integrate it with Islamic teachings. ${ }^{16}$

When viewed because of legal reform in Turkey and because of the issuance of the HattiSyarif imperium in 1839, it was because there was a struggle for authority between the sultan and the mufti about who had the right to legitimize sharia law. The reason for the issuance of trade and criminal laws in $1850 \mathrm{AD}-1858 \mathrm{AD}$ was due to anticipating the rise of uncontrolled trade. In 1915 AD, two royal edicts appeared, which reformed matrimonial law (relating to marriage), which was locally related to women's rights to divorce. The decree contains the permissibility of women to seek divorce based on being abandoned by their husbands because of their illness. The cause for the emergence of the decree is, many women are burdened because they are not allowed to divorce if left by their husband or because the husband suffers from the illness. ${ }^{17}$

The birth of an Act, which is a form of an amendment to the Act of 1917 that forbids polygamy, makes husband and wife equally in divorce, and from that moment on, divorce must be handed down in court with certain conditions not solely the husband's prerogative rights. The cause is the absence of rules governing the problem of polygamy so that many people are polygamy. Besides, in Turkey, equality between men and women before the law has not yet been realized, so it needs to be stressed that divorce imposed outside the court causes administrative problems.

${ }^{16}$ Sri Wahyuni, "Pembaharuan Hukum Keluarga Islam di Negara-Negara Muslim”, AlAhwal, Vol. 6, No. 2, 2013, p. 213.

${ }^{17}$ Umar FaruqThohir, "Reformasi Hukum Keluarga Islam Turki," dalamKhoirudinNasution, dkk (ed), Hukum Perkawinan danWarisan di Dunia Muslim Modern, (Yogyakarta: Academia, 2012)., p. 94-96. 
Politica, Vol. 7, No. 1, Januari-Juni 2020

\section{Turkish Family Law Material}

\section{Marriage Law}

a. Engagement (Khitbah)

Turkish family law encourages not to enter into special marriage agreements. If the engagement party has been carried out, it turns out the marriage agreement is canceled, and the party considered responsible for the cancellation is burdened with the obligation to pay compensation in the form of party costs that have been incurred. Hanafiyah scholars explain that khitbah aims to explore both parties so that it is possible to emerge feelings of love and like and like. Not explicitly explained, it must be held ceremonially except for the implementation of a marriage contract that is mandated to be exposed. The ceremonial purpose of a marriage contract is to be known by the general public. If there is a gift given at the failed engagement party, the prize in question must be returned in value within one year. Another case is the failure caused by the death of one party. In this case, the gift is considered lost. ${ }^{18}$

\section{b. Age of Marriage ('Umral-Zawaj)}

In the Turkish Law, the minimum age for a person to marry is 18 years for men and 17 years for women. In some instances the court can allow marriage at the age of 15 years for men and 14 years for women after obtaining permission from parents or guardians. In Hanafi'sfiqh about age restrictions on marriage, it does not concretely mention age, only explicitly stated that one of the conditions of marriage is sensible and baligh, as well as both being a general condition for the operationalization of all acts of a nuanced law. ${ }^{19}$

c. Forbidden from Marriage (Man'al-Zawaj)

Turkish law inventories the category of relationships that can establish obstacles to the union through marriage ties. The prohibition includes brothers, sisters, aunts, uncles, nieces, siblings, fathers, and also through marriage. The court also explicitly adopted adoption. Adoption in court is also referred to as one of the barriers to marriage, although the legal fiction of adoption is unknown in Islamic jurisprudence. In the mazhabHanafi of consensus on the causes of forbidden marriages are mentioned because ofmusaharah (marriage ties),

${ }^{18}$ M. Atho' Muzdhar, HukumKeluarga di Dunia Islam Modern..., p. 42

${ }^{19}$ M. Atho' Muzdhar, HukumKeluarga di Dunia Islam Modern..., p. 43. See too, Muhammad Jawad Mughniyah, Fiqh Lima Mazhab, (Penerjemah) Afif Muhammad, (Jakarta: Lentera Basritama, 1999), p. 317-318. 
Politica, Vol. 7, No. 1, Januari-Juni 2020

cohesion, marriage with siblings at one time, and marriage of free people with slaves. $^{20}$

d. Polygamy (Ta'addud al-Zawaj)

Turkish law prohibits more than one marriage as long as the first marriage is ongoing. The law states that a person is not married if he does not prove that the first marriage broke up because of death, divorce, and annulment. ${ }^{21}$ The prohibition of polygamy in the Civil Code of 1926 prohibits second marriages and so on. So that a man who has a legal wife, the second marriage is not considered legally valid. ${ }^{22}$ The permissibility of polygamy by the Koran under certain conditions has been changed voluntarily by Turkish legal regulations. The reason, as stated by some Turkish intellectuals, is that the Qur'ani legislation on the matter was a great improvement over eternal polygamy. The changing social conditions in Turkey have made polygamy impossible. The mazhabHanafi, as with other mazhab, permits the practice of polygamy by providing certain specified conditions such as being able to do justice to all his wives, both material and immaterial.

e. Wedding reception (Walimatul'Urs, Salomnization of Marriage)

The Turkish Civil Law states that marriages may be celebrated following their respective religions if desired, but registration is carried out before the celebration. After the formality requirements are met following applicable regulations, both partners may celebrate the marriage. In the Hanafifiqh, it is stated that by definition,walimah means bridal food or food served for banquets or other. According to JumhurUlama, the legal implementation of walimah is sunnahmuakkadah while attending the invitation according to Hanafiyah is sunnah. This view is different from the view of JumhurUlama, which obliges to attend the invitation. $^{23}$

f. Marriage Cancellation

A marriage must be canceled under the Turkish Civil Law under the following conditions: 1) One of the parties has been married when married; 2) One party at the time of marriage suffers from mental illness or other permanent illness; and 3) Marriage is prohibited. According to Hanafiyah, marriage is considered null and void if there are harmony or the conditions in the marriage that are not fulfilled, such as the marriage of a child who has not aged tamyiz, marriage with one of the mahram and others. The consequences are not halal screwed up,

\footnotetext{
${ }^{20}$ Vita Fitria, "HukumKeluarga di TurkiSebagaiUpayaPerdanaPembaharuan..., p.8-9.

${ }^{21}$ M. Atho' Muzdhar, HukumKeluarga di Dunia Islam Modern..., p.44.

${ }^{22}$ Sri Wahyuni, "PembaharuanHukumKeluarga Islam di Negara-Negara Muslim..., p. 216.

${ }^{23}$ M. Atho’ Muzdhar, HukumKeluarga di Dunia Islam Modern..., p. 45.
} 
Politica, Vol. 7, No. 1, Januari-Juni 2020

are not obliged to pay dowry, income, and are not obliged to obey and do not establish amusarahah relationship. If the two couples, as mentioned, had a chance to get together (husband and wife), the judge must separate them by force and do not applyiddah to the woman. ${ }^{24}$

\section{Divorce and Separation (Divorce and Separation)}

According to Turkish law,six things allow husband and wife according to the court to issue a divorce decree, provided that even though the divorce decree has been issued, the court may provide judicial separation if reconciliation between partners allows. If judicial segregation is provided and no reconciliation occurs between the two until the end of the given period, either party may request a divorce. These six things are: 1) One party has decided; 2) One party causes injury to the other party; 3) One of the parties has committed a crime which makes the marriage relationship intolerable to be continued; 4) One of the parties moves house in an unethical manner or without any apparent reason for at least three months; 5) One party suffers from mental illness which makes marital relations intolerable, which is stated with the doctor's statement within at least three years; and 6) Husband and wife relations are so tense that marital relations cannot be tolerated. ${ }^{25}$

Inthe Ottoman Law of Family Rights(Qanun Qarar al-Huquq Al-a'ilah alUsmaniyah) in 1917, article 38 stipulates the permissibility of divorce taklik for a wife that her husband cannot remarry with another woman (polygamy). In 1915, the Sultan stated in his decree that the wife could ask for a divorce if the husband left his wife. Another decree was issued in the same year, a wife can ask for a divorce because the husband has an illness that makes it impossible to live together as husband and wife. ${ }^{26}$

\section{Compensation}

In the Turkish Law, it is stipulated that the court may determine the compensation money that must be paid by one of the husband and wife for the hurt partner. Associated with compensation as intended, if his wife cannot serve the losses incurred in the form of a husband, the wife's livelihood, according to the expert'sfiqh four mazhab sects, is dead. Conversely, if the wife is disadvantaged because the husband cannot serve it, the wife still gets a living. ${ }^{27}$

\footnotetext{
${ }^{24}$ M. Atho' Muzdhar, HukumKeluarga di Dunia Islam Modern..., p. 46.

${ }^{25}$ M. Atho' Muzdhar, HukumKeluarga di Dunia Islam Modern..., p. 48-49.

${ }^{26}$ KhairuddinNasution, Status Wanitadi Asia Tenggara, (Jakarta: Inis, 2002), p. 245.

${ }^{27}$ Vita Fitria, "HukumKeluarga di TurkiSebagaiUpayaPerdanaPembaharuan..., p.11.
} 
Politica, Vol. 7, No. 1, Januari-Juni 2020

\section{Inheritance law}

The third book of the Turkish Civil Law deals with inheritance. This book introduces all inheritance schemes without a will, which was adopted from the Switzerland Act. The mazhabHanafi of inheritance law had previously been followed in Turkey until 1926 and was later replaced by a new scheme. One of the essential parts offered is the principle of equality between men and women related to inheritance. The Koran shows the level of closeness of the proposition that male equality must occur in the second division of women. The Turkish Civil Law stipulates that children who are left dead by fathers must get the same inheritance. Turkey also has a trust and adoption law of 1958 in which there are legal reforms regarding the rights and status of adopted children or the adoption of children. The law explains that adopted children get the same rights and obligations as biological children. The adopting family must also be able to meet the financial needs of children. $^{28}$

\section{Conclusion}

In the whole territory of the Ottoman Empire and considered the first Civil Code in the Islamic world was al-Majallat al-Ahkam al-Adliyah. The majority of alMajallah's material legal sources are taken from the view of the mazhabHanafi of thought. In Turkey,al-Majallah was replaced with the Swiss Civil Code in 1926 as one of the effects of the secularisation carried out by the current Turkish government under the leadership of Mustofa Kemal Attaturk. In 1850 AD-1858 AD was issued trade and criminal laws to anticipate the rise of uncontrolled trade. In 1915 AD two royal edicts appeared which reformed matrimonial law (which related to marriage) which contained women may seek divorce on the grounds of being abandoned by a husband because of the illness suffered by her husband and the birth of a Law which was a form of an amendment to the 1917 Law that forbade it polygamy, making husband and wife equally in a divorce. At present, family law in Turkey covers marital law in which matters are governing engagement, marriage age (18 years for men and 17 years for women), people who are prohibited from marriage, and so forth. In Turkish family law also discussed divorce issues (the existence of equal rights between men and women), compensation for husbands, or wives who have been hurt or harmed and inheritance.

\footnotetext{
${ }^{28}$ Mardani, HukumKeluarga Islam di Dunia Islam Modern,(Yogyakarta: GrahanaIlmu, 2011), p. 93 .
} 
Politica, Vol. 7, No. 1, Januari-Juni 2020

\section{REFERENCES}

Abbas,Suardi, 2016,"Keberanjakan Dari Konsep Konvensional Ke Dalam Perundang-undangan Hukum Keluarga Islam”, Asas, Vol. 8, No. 2.

Fitria, Vita, 2012,"Hukum Keluarga di Turki Sebagai Upaya Perdana Pembaharuan Hukum Islam", Humanika, Vol. 12, No. 1.

Fuad,Mahsun, 2019,"DinamikaSekularisasidanPembaharuanHukumWaris Islam di Turki”, Al-Mabsut, Vol. 13, No.2.

Huda,Miftahul， 2017,"RagamBangunanPerundang-UndanganHukumKeluarga di

Negera-Negara Muslim Modern (KajianTipologis)", Al-Manahij:

JurnalKajianHukum Islam, Vol. 11, No. 1.

Mahmood,Tahir, 1972,Family Law Reform in The Muslim World, Bombay: Tripathi.

Mardani, 2011, Hukum Keluarga Islam di Dunia Islam Modern, Yogyakarta: Grahana Ilmu.

Mughniyah,Muhammad Jawad, 1999,Fiqh Lima Mazhab, (Penerjemah) Afif Muhammad, Jakarta: Lentera Basritama.

Muzdhar,M. Atho', 2003,HukumKeluarga di Dunia Islam Modern,Jakarta: Ciputat Press.

Nasution, Khairuddin, 2002, Status Wanita di Asia Tenggara, Jakarta: Inis.

Rojak, Encep Abdul, 2019,"Hukum Keluarga di Dunia Islam (Perbandingan Kitab Majallatul Ahkam di Turki dan Kompilasi Hukum Islam di Indonesia)", Tahkim: JurnalPeradabandanHukum Islam, Vol. 2, No. 1.

Suchamdi, 2013,"Heterogeneous Perundang-UndanganHukumPerkawinan NegaraNegara Muslim Modern", Kodifikasia: Jurnal Penelitian Islam, Vol. 7, No. 1.

Thohir,Umar Faruq, 2012,"Reformasi Hukum Keluarga Islam

Turki,"dalamKhoirudinNasution, dkk (ed), HukumPerkawinandanWarisan di Dunia Muslim Modern, Yogyakarta: Academia.

Wahid,Ahmad Bunyan, 2014,"ReformasiHukumKeluarga di Dunia Muslim, JurnalWacanaHukum Islam danKemanusiaan, Vol. 14, No. 1.

Wahyuni,Sri, 2013,"PembaharuanHukumKeluarga Islam di Negara-Negara Muslim", Al-Ahwal, Vol. 6, No. 2.

Zayyadi,Ahmad, 2014,"ReformasiHukum di TurkidanMesir (TinjauanHistorisSosiologis)", Al-Mazahib, Vol. 2, No. 1.

Zein,Fitriyani, 2017, "KekerasanDalamPerkawinandanNusyuzdalamHukumKeluarga di Turki, Malaysia, Sudan, Yordan, dan Indonesia", Salam: JurnalSosialdanBudayaSyar'I, Vol. 4, No. 1. 